\title{
Staffing A New Sales Force: A Human Resource Management Case Study
}

Lynn M. Murray, Pittsburg State University, USA

Arthur K. Fischer, Pittsburg State University, USA

\begin{abstract}
An HRM case used to encourage student thought and discussion concerning staffing and management of a new sales force. Midwest Education, Inc.: A Human Resource Management Case is used to exemplify many of the human resource problems encountered in a typical organization. It provides history and background of the company, Midwest Education, Inc. (which is closely modeled after a major developer and supplier of educational materials). With this background, the case presents the staffing issues which arise as the company seeks to change from using manufacturer's representative firms to sell their products to having an in-house sales force.
\end{abstract}

Keywords: HRM case, staffing, sales force management

\section{INTRODUCTION}

Midwest Education, Inc. is a major supplier of educational materials for the United States. The company focus is on learning tools and systems for use in technology, science and business classrooms. In addition, it develops and provides books, manuals, videos, software and hardware used in the fields of technology education, instructional development and business applications.

The company has its headquarters and primary manufacturing plant in a major Midwest community. In addition, the Creative Development offices are located in Massachusetts and California. Transportation, Service and Maintenance facilities are headquartered out of Texas, with major branches in Baltimore and Phoenix.

\section{COMPANY HISTORY}

Midwest Education was started by Henry and Mary Dalton in 1985. Dr. Henry Dalton was an industrial arts teacher before he got his MBA and went on to get his Ph.D. in Technology Education. Mary was a software developer who also taught business seminars. At that time a new wave of emerging technology was beginning to alter the way people learn and communicate. By developing Midwest Education, Inc. the Daltons began work in an exciting new field. They found a vast market for quality tools that educated people on how to use all the new technology. Dr. and Mrs. Dalton are in semi-retirement now and travel extensively, but remain major shareholders in the business. They personally hired the CEO when they went into semi-retirement.

The company started with about fifty employees, but has grown consistently and now has a total of 416 employees within its three major divisions: 183 employees work in the Manufacturing Division, 123 work in the Creative Development Division and 135 work in the Transportation, Service and Maintenance Division. There are also 71 employees working at the headquarters in Kansas City (including the corporate staff).

At the end of the 1990s it became apparent that international business was becoming the rule rather than the exception. The company went international in 1999 and now is exporting to three European, two Latin American, and two Pacific Rim countries. The Global Operations Division is located within the headquarters. 


\section{HEADQUARTERS}

The corporate headquarters are in Kansas City. The CEO of Midwest Education, Inc. is Judith Lund. Ms Lund was hired by the Daltons in 2004 when they decided to take a less active role in the company while remaining major shareholders. Ms. Lund has an MBA in business management, and was previously the CEO of a small telecommunications company. In her previous position, Ms Lund had successfully steered the company out of financial difficulties by raising stock value. She had initiated a strong advertising campaign and had put the company 'in the black' for the first time in seven years.

The COO of Midwest Education, Inc. is Frank Rose. Frank has been with the company since 1995. Mr. Rose, a cousin of Dr. Dalton, had a successful career with an international business training group in California. His desire to move back to his home town of Kansas City came at a time when the Daltons were looking for a COO. He has worked out well for the company.

The Human Resources Department is also located at the headquarters. The Vice President for Human Resources is Lawrence Wilson. Mr. Wilson has a degree in industrial and organizational psychology and an MBA. He has been with the company for 11 years. He started out as a generalist and was promoted as he showed good judgment with hiring and earned his MBA at the same time.

Within the Human Resources Department there are four sections:

1. Staffing, the head of this section is Patrick Shew.

2. Compensation and benefits section, headed by Michael Martin.

3. Labor management relations section, headed by Keith Lane.

4. Training, career development and performance appraisal section, headed by Cynthia Burns.

There are also human resource specialists in each of the three divisions around the country.

\section{SITUATION}

Lawrence Wilson, Midwest Education's Vice President of Human Resources, sat down at his desk after an executive committee meeting at which Carol Alphonse was introduced as the firm's new - and first - Vice President of Sales and Marketing. After the meeting, Carol had walked with him back to his office and told Lawrence that she was looking forward to working with him and his staff in building the sales force and that she'd like to get started on a staffing plan quickly. They arranged a meeting for the following week. He thought for a few minutes and then asked Patrick Shaw, section head of staffing, to explore how the human resource needs of a sales force differ from their current human resource.

“OK. Let's get started. Midwest Education is bringing the sales function in-house. As you know, we've worked with a number of manufacturer's representative firms to move our product, and that's worked really well. But we're at the point now where it makes more fiscal sense to field our own domestic sales force. I'm meeting with our new Vice President of Sales and Marketing and her team next week to discuss staffing. Patrick, what can you tell us about staffing a sales force?"

Patrick stood up. "Before we discuss the recruiting methods and avenues, I'd like to briefly touch upon the various types of salespeople, their tasks, and their challenges, as these have a great deal to do with recruiting and compensation.:"

"First of all, we can classify salespeople as being inside sales or outside sales. The use of inside sales forces is increasing, as they are less expensive in terms of both salary and sales expenses (no travel). These folks work out of an office and sell to non-retail customers. While some inside sales forces are order-takers who passively accept orders, I would expect that ours would be order-getters who would actively call on customers through the telephone or other non-face-to-face methods." 
"On the other hand, outside sales forces, or field sales, call on customers and potential customers at their places of business, typically face-to-face. Field sales positions, while more expensive because of higher compensation and higher costs due to travel and entertainment expenses, are the most appropriate in building and maintaining long-term relationships with new and existing customers."

"The job analysis is critical here - two elements of our company and products in particular are relevant. First, our markets tend to be varied and complex - sometimes an individual teacher can make the decision, sometimes the school board must approve any purchase. Most of the time our salespeople will be calling on multiple people in each school and in each school district. Second, we have a broad product line, and many products are technically complex, requiring some significant expertise on the part of our salespeople. There is one other element that will affect both recruiting and compensation: the degree of autonomy afforded to the sales force. The more autonomy, the more experience we need to look for and the more compensation needs to align with company and salesperson interests."

"Now about recruiting. There are multiple avenues to recruit salespeople, some we're used to using, some will be new. I've created a table detailing these sources and the advantages and disadvantages of each source (see Table 1). One area I'd like to address in detail, though, is the use of headhunters. We've rarely, if ever, used them, but they are an option to consider as we begin to build a sales force, particularly those recruiters that specialize in recruiting for sales positions. Just as with other recruiting efforts, headhunting firms offer both advantages and disadvantages. First, they have experience in both human resources and sales recruiting. They will also have broader access to the pool of potential applicants and are experts in screening applicants, thus providing us with a pool of highly qualified candidates. Finally, they only get paid if they successfully place a salesperson with a company. This is also a disadvantage, as they typically are paid a fairly hefty sum, and we'll have to take care in selecting the right headhunter and in overseeing the process - many recruiting firms use a shotgun approach and flood the client with unsuitable candidates."

"As for screening candidates, there are a number of methods that we can use, either singly or in combination. Our standard employment application, of course, provides significant amounts of information about the candidate, such as work chronology and education. Not only do applications help us screen for needed qualifications, they also provide preparatory information for interviews. While all candidates will provide a resume, the application helps ensure that we have uniform information from all candidates."

"Tests are increasingly used in screening processes for sales people - intelligence, aptitude, and personality tests. However, even though testing has improved, many sales managers are leery of the usefulness of testing in predicting success in sales positions. Aptitude tests, for example, measure current skills, and, as many selling skills can be taught, relying on aptitude tests may cause potentially successful candidates to be rejected. As to personality traits, no single personality trait is consistently linked to productivity across selling jobs or firms; therefore tests that purport to measure sales ability often just work for specific selling jobs or firms. Additionally, as standardized tests capture the norm, talented and creative people who might make significant contributions could be overlooked. Sales managers also worry about those who know the right answers to provide on tests - right answers that don't really reflect the candidate's true feelings or behavior. Finally, many worry that extensive testing is or could be seen as an invasion of privacy and would thereby discourage good candidates."

"Personal interviews are critical and should be used as both a screening and as a selection tool. Sales managers use interviews to gauge candidate's presentation ability, personality, experience, and ability to think on her feet. Interviews are most effective when the candidate is interviewed by several interviewers and when interviews are used with other selection tools."

"We also often see realistic job previews (RJPs) used. RJPs provide an opportunity for the candidate to experience the job and to ask salespeople questions. They also allow an experienced salesperson to observe how the candidate interacts with customers and to gauge the candidate's experience and ability to do the job."

"Finally, we should continue our reference checking procedures. Reference checks, while time-consuming and costly, can confirm or disconfirm the truthfulness of resume and application information." 
After Patrick finished, Lawrence thanked his team and began to prepare for his first meeting with Carol Alphonse and her team.

Student activity: at this point, students should think about the information Lawrence needs to develop recruiting and selection plans for the new sales force. This can be done with the entire class, in groups, or as individuals.

"Lawrence, thanks for meeting with us this morning. Have you met Delaney Fox and Mark Shea? Delaney is to head our field sales force and Mark is our inside guy. I'm going to let Delaney start."

“Thank you, Carol. Lawrence, I've heard terrific things about the HR division and I'm really looking forward to working with you and your team on this project. For the field sales force, we anticipate slowly building each district. We've gained agreement from the current manufacturer's rep firms to help us in each territory during the transition. As part of these agreements, however, we've had to agree to not recruit their representatives."

"Ultimately, we plan to field five districts, each with a district manager. At this point, each salesperson will be a generalist, handling all aspects of the sales process and selling our full line. At some point the sales force will specialize, but not anytime soon. The geographic regions are the Northeast, the Southeast, the Southwest, the West Coast, and the Mountain Plains. As Kansas City is located in the Mountain Plains district, that will be the first to rollout. With the exception of the Mountain Plains district manager, we will not be providing physical office space for district managers or for salespeople, rather, they will be provided with necessary equipment. This will help keep our overhead costs down."

"Each district will be comprised of a district manager who will oversee the field sales force, eight to ten sales representatives, and one or two key account managers who will work closely with the largest accounts in the district (see Figure 2). Initially, our salespeople will be spending considerable amounts of time building relationships with existing and potential customers; after the first year or two, however, the emphasis will shift toward generating sales, whether through existing customers or new customers. This isn't to say that relationship-building will not be a priority; it just won't be a priority to the exclusion of all else."

"Finally, I'd like the Mountain Plains district to hit the ground running by hiring primarily experienced salespeople. I can train them about the products we produce relatively quickly - good selling skills take much longer to develop."

“Thanks, Delaney. Mark, your turn."

"Right. We'll actually be constructing two inside sales forces: one that will focus on account management of smaller accounts and one that will focus on supporting the field sales force by prospecting and qualifying leads, customer service, and other promotional support (see Figure 1). My biggest concern, however, is finding the right people for the roles and then keeping them here and motivated."

"Finding people who combine the aggressiveness of a salesperson with the customer-focused empathy of a customer service person is going to be difficult. In addition, we'll be integrating web sales as another inside sales channel. While I'd prefer using as many of our existing customer service folks as possible, we'll still have to go outside the firm to find more."

"Motivating the inside sales forces is another challenge. Not only do they typically make less than field sales people, the role is often considered of lower status. One way to keep them motivated in the long-run is to use these roles as springboards into field sales. Firms have also focused on extensive training, generous bonuses for peak performance, recognition programs, and more opportunities for professional development, including more interaction with field sales teams and customers."

"We plan to house the inside sales staffs here in Kansas City. Ultimately, I expect we'll hire about 30-40 reps to work with the field sales force and about 75-100 reps to handle inside sales. This inside sales force will be 
handling in-bound calls, but more often will be calling on accounts through the telephone and web. We'll likely hire one supervisor for every 25-30 representatives. We'll also slowly build these two teams, and we'll be looking for both experienced and inexperienced representatives."

After the meeting, Lawrence returned to his office and began to think about staffing the new sales forces. He wanted to develop preliminary staffing plans to present to Carol and her team at their next meeting.

\section{ASSIGNMENT}

Students will be divided into teams, with each team addressing the needs of a different type of sales force (field sales, small account sales, and field sales support). Specifically, students should be sure to address the following concerns:

1. What type of compensation or combination of compensation methods should be used? Why?

2. What would be appropriate recruiting sources for each sales force initially? Why? Would you see any changes in subsequent years?

3. Discuss the selection process that should be used. Who from Midwest Education should be included in the selection process? At what point should each participant be included?

\section{AUTHOR INFORMATION}

Dr. Lynn Murray is an Assistant Professor of Marketing in the Department of Management and Marketing at Pittsburg State University. She has worked in the hospitality industry for firms such as YUM! and Disney, and in areas such as advertising sales representative and human resources recruiter. In her teaching she emphasizes learning and application through the use of live cases.

Dr. Art Fischer is a University Professor of Management in the Department of Management and Marketing at Pittsburg State University. He is a FELLOW with the American College of Healthcare Executives, and is a retired healthcare executive. 
Table 1.

\begin{tabular}{|c|c|c|}
\hline Source & Advantages & Disadvantages \\
\hline Internal & $\begin{array}{l}\text { Candidates are known quantity with established } \\
\text { performance records } \\
\text { Candidates have shorter learning curve in regards } \\
\text { to company and its products } \\
\text { Internal hire can bolster employee morale }\end{array}$ & $\begin{array}{l}\text { Internal hires seldom have extensive sales } \\
\text { experience } \\
\text { Can cause conflict with other departments as } \\
\text { recruiting, hiring and training burden simply } \\
\text { shifts to the cannibalized department }\end{array}$ \\
\hline Referrals & $\begin{array}{l}\text { Candidates often knowledgeable about job } \\
\text { demands } \\
\text { Candidates often knowledgeable about industry } \\
\text { Candidates may bring along customers }\end{array}$ & $\begin{array}{l}\text { Can be difficult for new hires to unlearn previous } \\
\text { employer's(s') practices } \\
\text { May begin a recruiting war with competitors } \\
\text { Ethical considerations (money invested in } \\
\text { sourcing and training; trade secrets) }\end{array}$ \\
\hline Advertisements & $\begin{array}{l}\text { Broad reach } \\
\text { Can be targeted to sales professionals through } \\
\text { trade publications } \\
\text { - Commonly used for less demanding sales jobs that } \\
\text { don't require special qualifications }\end{array}$ & $\begin{array}{l}\text { Too many unqualified applicants causes increased } \\
\text { costs in screening }\end{array}$ \\
\hline $\begin{array}{l}\text { Educational } \\
\text { Institutions }\end{array}$ & $\begin{array}{l}\text { College grads often more socially adept } \\
\text { Some track record (grades, activities) to predict } \\
\text { performance } \\
\text { Candidates from institutions with selling \& sales } \\
\text { management curricula are productive sooner (by } \\
50 \% \text { ) and turnover less (35\%) }\end{array}$ & $\begin{array}{l}\text { Often hires have little experience and need more } \\
\text { training } \\
\text { College-educated hires may be more likely to job- } \\
\text { hop }\end{array}$ \\
\hline Internet & $\begin{array}{l}\text { Indicates candidates' comfort level with } \\
\text { technology } \\
\text { Increases screening efficiency of processing } \\
\text { applications }\end{array}$ & $\begin{array}{l}\text { Uniqueness of sales positions and necessity for } \\
\text { personal interviews make use for recruiting } \\
\text { problematic - best used as a screening tool } \\
\text { Possible EEO concerns }\end{array}$ \\
\hline $\begin{array}{l}\text { Professional } \\
\text { sales recruiting } \\
\text { agencies }\end{array}$ & $\begin{array}{l}\text { Locates and screens qualified sales professionals } \\
\text { Reduces time and effort to build sales force }\end{array}$ & $\begin{array}{l}\text { Requires detailed description of required } \\
\text { qualifications } \\
\text { Agency must be carefully chosen and monitored to } \\
\text { ensure qualified candidates referred } \\
\text { Costs }\end{array}$ \\
\hline
\end{tabular}




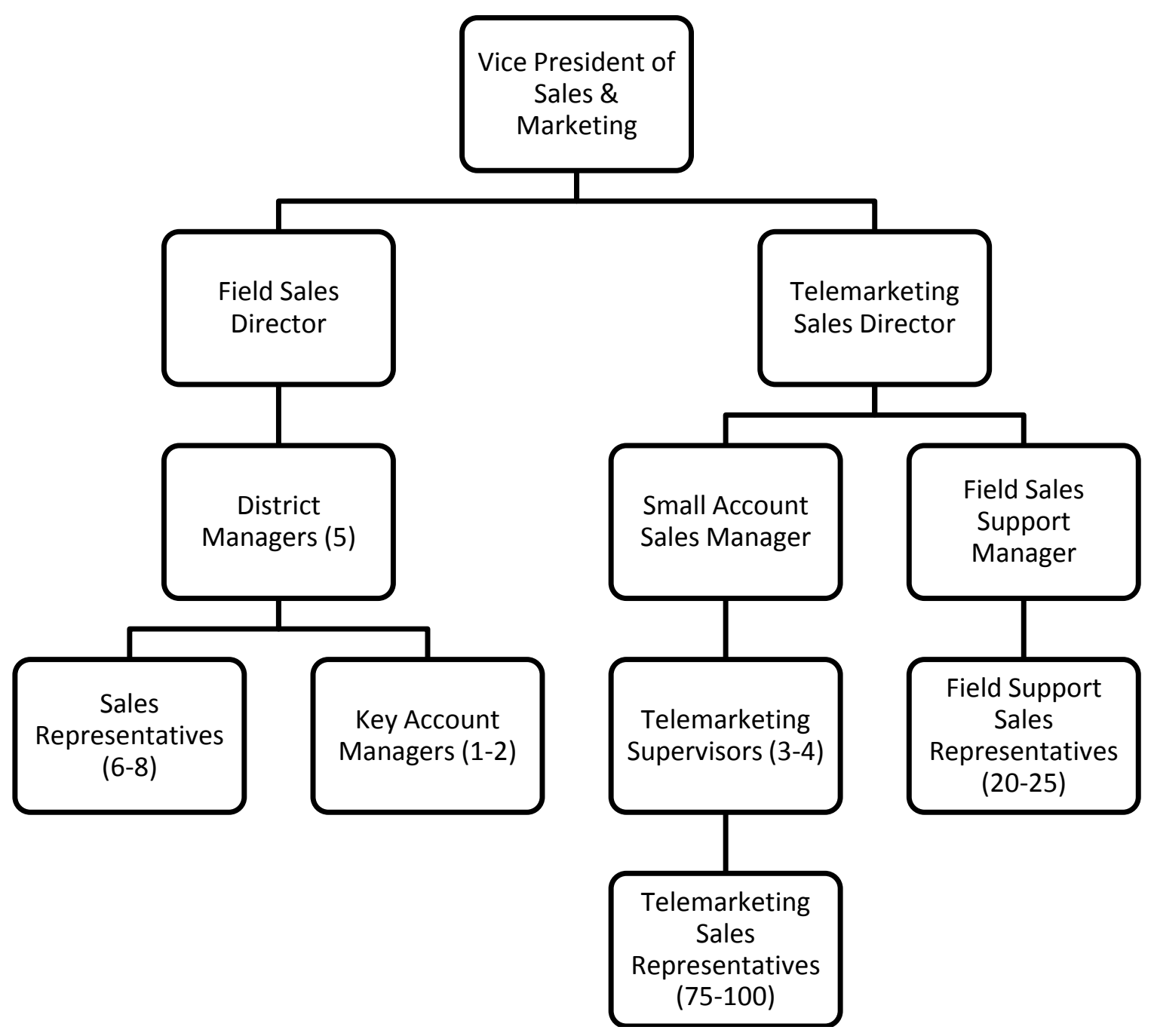

Figure 1: Sales Force Organizational Chart 
NOTES 